Jurnal Geografi, Edukasi dan Lingkungan (JGEL) Vol. 5 No. 1, Januari 2021:27-32

P-ISSN: 2579-8499; E-ISSN: 2579-8510

Doi: https://doi.org/10.22236/jgel.v5i1.5311

Website: http://journal.uhamka.ac.id/index.php/jgel

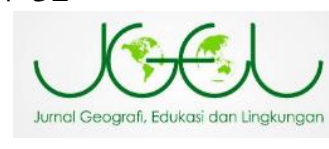

\title{
Pengelolaan Destinasi Pariwisata Berkelanjutan: Kasus Tanjung Lesung Provinsi Banten
}

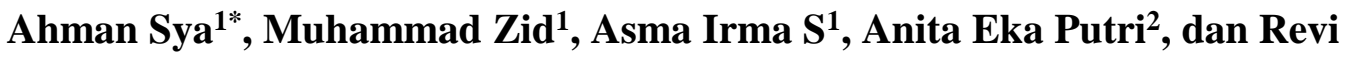 \\ Mainaki $^{2}$ \\ ${ }^{1}$ Departement Pendidikan Geografi, Fakultas Ilmu Sosial, Universitas Negeri Jakarta, Indonesia \\ ${ }^{2}$ Departemen Pendidikan Geografi, Fakultas Keguruan dan Ilmu Pendidikan, Universitas \\ Siliwangi, Indonesia
}

*E-mail: hm.ahmansya@ gmail.com

Received: 23072020 / Accepted: 1901 2021/ Published online: 29012021

\begin{abstract}
ABSTRAK
Kolaborasi penta-helix (akademisi, bisnis, pemerintah, komunitas, dan media) adalah faktor kunci pengelolaan destinasi pariwisata berkelanjutan. Pariwisata merupakan salah satu industri tercepat dan terbesar di Indonesia yang menjadi sektor terkuat pada lima tahun terakhir. Untuk itu, tujuan penelitian ini yaitu untuk menentukan (1) aksesibilitas tujuan, atraksi, dan amenitas (3-A), (2) pentahelix ABGCM (akademisi, bisnis, pemerintah, komunitas, dan media) komitmen dalam pengembangan destinasi, (3) bentuk atau jenis promosi pariwisata, (4) langkah untuk menyiapkan sumber daya manusia pariwisata, dan (5) langkah dan model baru untuk mempercepat promosi destinasi pariwisata Tanjung Lesung berbasis pengelolaan destinasi pariwisata berkelanjutan. Metode yang digunakan yaitu deskriptif analitis untuk mempelajari dan menganalisis berbagai indikasi, data, dan fenomena. Hasil analisis menunjukkan bahwa pengembangan sumber daya manusia (HRD) belum memenuhi persyaratan minimum sertifikasi kompetensi. Untuk mempercepat pengembangan dan peningkatan destinasi Tanjung Lesung, perlu diterapkan model baru pariwisata berbasis masyarakat berkelanjutan dengan strategi pro-job, pro-poor, pro-growth, dan pro-environment.
\end{abstract}

Kata Kunci: Kolaborasi Penta-Helix, 3A (Aksesibilitas, Atraksi, Fasilitas), dan Pariwisata Berbasis Komunitas

\section{ABSTRACT}

A penta-helix collaboration (academics, business, government, community, and media) is a key factor of sustainable tourism destination management. Tourism, one of the fastest and largest industries in Indonesia, has been the strongest sector found in the last five years. Based on it, the aim of this research to identification 1). The support of the 3-A's (Accessibility, Attractions, and Amenities); 2). Pentahelix ABGCM (academics, business, government, community, and media) commitment to destination development, (3) types of tourism promotion, (4) prepare tourism human resources, and (5) new steps and models to accelerate promotion Tanjung Lesung tourism destination based on sustainable tourism destination management. The method used is descriptive analytical to study and analyze various indications, data, and phenomena. The result of this research identification that promotional strategy should be based on the POSE (Paid media, Own media, Social media, and Endorser) model. The human resources development (HRD) have not met the minimum requirements for competency certification. To accelerate the development and improvement of Tanjung Lesung 
destination, it is necessary to apply a new model of sustainable community based tourism with pro-job, pro-poor, pro-growth, and pro-environment strategy.

Keywords: Penta-Helix Collaboration, $3 A$ 's (Accessibility, Attractions, Amenity), and Community Based Tourism.

\section{PENDAHULUAN}

Potensi Pariwisata merupakan alat yang efektif di negara berkembang, khususnya Indonesia (Kiper, 2013) (Franjaya \& Prastiwi, 2020). Sejak 2015, sektor pariwisata telah ditetapkan sebagai salah satu dari lima sektor prioritas pembangunan nasional, bersama dengan infrastruktur, maritim, energi, dan pangan (Kemenpar, 2016). Kebijakan ini didasarkan pada potensi wisata alam, budaya, dan buatan manusia Indonesia untuk membangun kesejahteraan masyarakat. Seperti diketahui, Indonesia adalah negara kepulauan terbesar di dunia (17.504 pulau), dihuni oleh 265 juta penduduk, 525 kelompok etnis, berbicara 250 bahasa lokal (Dibra, 2015). Kepulauan ini mencakup 8,3 juta meter persegi, terdiri dari $70 \%$ laut dan $30 \%$ daratan (Leslie , 2015).

Indonesia, seperti berdiri, memiliki atraksi untuk wisata alam, budaya, dan buatan manusia, dan diyakini sebagai sektor pengembangan propekerjaan, pro-miskin, pro-pertumbuhan, dan pro-lingkungan, yang mampu berkontribusi pada PDB terbesar (produk domestik bruto) di masa depan (World Travel \& Tourism Council, 2018). Terutama, pariwisata telah menyebabkan penciptaan lapangan kerja dan itu membawa pembangunan ekonomi dan sosial (Buckley, 2012). Sebagai fokus pengembangan pariwisata di luar Bali, sepuluh destinasi prioritas yaitu Danau Toba (Sumatera Utara), Tanjung Kelayang (Belitung), Tanjung Lesung Banten, Kota Tua dan Kepulauan Seribu (DKI Jakarta), Borobudur (Jawa Tengah), Bromo-Tengger-Semeru (Jawa Timur),
Mandalika (Nusa Tenggara Barat), Labuan Bajo (Nusa Tenggara Timur), Wakatobi (Sulawesi Tenggara), dan Morotai, 2018) (Kurniawati et al., 2018). Selain itu, destinasi prioritas khusus lainnya ditetapkan sesuai dengan karakteristiknya, misalnya wisata budaya, wisata halal, wisata kuliner, wisata bahari, wisata niche, geo-park, dan lain-lain (Lohmann, 2018).

Penelitian ini dilakukan di destinasi prioritas Tanjung Lesung, Provinsi Banten, dengan berfokus pada aspek "Sustainable Tourism Destination Management" (Morpeth, 2015). Tujuan penelitian ini adalah untuk menentukan (1) aksesibilitas tujuan, atraksi, dan amenitas (3-A), (2) pentahelix ABGCM (akademisi, bisnis, pemerintah, komunitas, dan media) komitmen dalam pengembangan destinasi, (3) bentuk atau jenis promosi pariwisata, (4) langkah untuk menyiapkan sumber daya manusia pariwisata, dan (5) langkah dan model baru untuk mempercepat promosi destinasi pariwisata Tanjung Lesung berbasis pengelolaan destinasi pariwisata berkelanjutan.

\section{METODE}

Metode yang digunakan dalam penelitian ini adalah deskriptif analitis untuk mempelajari dan menganalisis berbagai indikasi, data, dan kejadian yang ada dan terjadi sekarang, yang terkait dengan pengelolaan destinasi pariwisata berkelanjutan di Tanjung Lesung (Lohmann, 2018). Pola hubungan (keterkaitan, interaksi, dan saling bicara antara manusia dan lingkungan alam di Tanjung Lesung dan sekitarnya, termasuk keberlanjutan, pemerataan, keamanan, 
risiko lingkungan, pendidikan dan komunikasi, investasi dan kerja sama internasional) dianalisis secara komprehensif untuk melihat perannya dalam mempercepat kemajuan pengembangan destinasi (Lu \& Nepal, 2009).

Populasi penelitian ini adalah akademisi, pengusaha pariwisata, pemerintah daerah, praktisi/komunitas pariwisata, dan media pariwisata. Sampel diambil dengan melakukan stratified random sampling proporsional sebesar $10 \%$ dari total populasi atau 58 orang (BPS, 2019). Pengumpulan data dilakukan melalui wawancara dengan menggunakan pedoman wawancara dan hasilnya dianalisis dengan menggunakan triangulasi dan analisis kualitatif (Bramwell et al., 2017).

\section{HASIL}

Menemukan Aksesibilitas, Atraksi, dan Fasilitas (3-A)

Hasil penelitian menunjukkan bahwa Tanjung Lesung sebagai destinasi prioritas masih memiliki keterbatasan dalam pemenuhan persyaratan aksesibilitas, atraksi, dan amenitas (3A). Akses dari ibu kota Jakarta ditempuh dengan menempuh jarak $160 \mathrm{~km}$, membutuhkan 4-6 jam perjalanan darat. Sarana transportasi lain melalui laut atau udara belum ada. Dengan demikian, keterbatasan akses ini mengakibatkan terbatasnya jumlah wisatawan yang datang ke Tanjung Lesung. Apalagi belum ada penyedia jasa transportasi khusus ke Tanjung Lesung. Waktu puncak pariwisata hanya terjadi pada akhir pekan dan hari libur lainnya. Untuk mengatasi masalah aksesibilitas di masa depan, jalan tol dari Serang ke Panimbang (dekat Tanjung Lesung) dengan panjang $83,9 \mathrm{~km}$ kini sedang dibangun. Bila selesai, jarak antara Jakarta dan Tanjung Lesung dapat ditempuh hanya dalam waktu sekitar 2,5 jam.
Berdasarkan segi atraksi, Tanjung Lesung memiliki beberapa jenis atraksi untuk wisatawan, yaitu alam dan budaya serta atraksi buatan manusia. Situs pemandangan gunung Krakatau, pemandangan matahari terbenam, pasir putih, pantai yang indah, pertunjukan budaya Banten, kuliner, mode, kerajinan, dan atraksi buatan manusia seperti pusat budaya Mongolia adalah beberapa daya tarik destinasi ini. Namun, layanan manajemen acara khususnya belum ada, atraksi belum dijadwalkan berdasarkan standar, dan promosi masih terbatas.

Untuk meningkatkan daya tarik Tanjung Lesung, Pemerintah meningkatkan objek wisata alam, memperkaya atraksi budaya, dan membangun lebih banyak atraksi buatan manusia, misalnya, di atraksi bahari, pertunjukan budaya lokal berkolaborasi dengan masyarakat sekitar, pameran, dan acara olahraga massal. Ada unsur fasilitas yang memadai di destinasi ini, meskipun belum dapat dianggap sebagai standar internasional. Penginapan, restoran, dan gazebo juga tersedia. Masalahnya, karena jumlah wisatawan masih terbatas, banyak fasilitas ini yang kurang terawat, atau bahkan rusak sebelum digunakan. Hal ini membuat pelayanan perhotelan tidak memuaskan. Fasilitas TIK (Teknologi Informasi dan Komunikasi) yang memadai belum ada, sehingga menyulitkan wisatawan untuk berkomunikasi ke daerah terluar.

\section{Komitmen Pentahelix (ABGCM)}

Komitmen antara pemerintah pusat dan daerah dalam mengembangkan destinasi Tanjung Lesung cukup baik. Namun, komitmen dari akademisi, bisnis (industri pariwisata), masyarakat, dan media, tetap berjalan sendiri dan perlu ditingkatkan. Pemerintah masih sangat dominan dalam menginisiasi promosi destinasi tersebut. Masyarakat masih 
belum terkoordinasi dengan baik, industri pariwisata belum mandiri, akademisi masih kurang memperhatikan isu pariwisata, dan media belum memaksimalkan upaya mereka dalam mempromosikan pariwisata di Tanjung Lesung. Oleh karena itu, sistem pengembangan pariwisata untuk destinasi Tanjung Lesung masih berada pada level rata-rata $(=$ basic $)$, belum sistem yang berkelanjutan.

$\begin{array}{ccr}\begin{array}{c}\text { Komitmen } \\ \text { pengembangan }\end{array} & \begin{array}{c}\text { dalam } \\ \text { pariwisata }\end{array} & \text { konteks } \\ \text { harus }\end{array}$
mencakup empat aspek yaitu, anggaran, pengembangan destinasi, promosi, dan penyi penyusunan sumber daya manusia yang memenuhi kuantitas dan daya saing, kualitas, serta standar relevansi. Penugasan dan pembagian tugas untuk setiap elemen dalam pentahelix harus jelas, proporsional, dan profesional.

\section{Persiapan Pariwisata HR}

Ada istilah orang di belakang pistol. Meskipun destinasi Tanjung Lesung unik dan menarik, namun tidak akan memiliki citra yang baik jika SDM tidak memenuhi standar kuantitas, kualitas, dan daya saing, serta akibatnya juga akan mempengaruhi jumlah wisatawan yang datang. Bisa lebih buruk ketika mereka yang telah mengunjungi tempat itu tidak tertarik untuk mengunjunginya kembali karena layanan yang tidak memadai. SDM pariwisata di Tanjung Lesung masih belum bersertifikat, baik nasional maupun internasional berdasarkan standar Mutual Recognition Arrangement on Tourism Professionals (MRA-TP). Proses rekrutmen belum memenuhi standar kompetensi pariwisata. Lulusan pendidikan nonwisata masih dipekerjakan di industri pariwisata Tanjung Lesung. Lulusan pendidikan non-pariwisata membutuhkan pelatihan khusus untuk bekerja di industri pariwisata, dan tentunya akan menjadi kerja keras untuk dilakukan.

Diperlukan kolaborasi dengan perguruan tinggi pariwisata atau sekolah menengah pariwisata (SMK). Secara mandiri, industri pariwisata juga perlu melakukan pelatihan pra-layanan dan pelatihan dalam layanan tentang sumber daya manusia mereka. Diharapkan SDM Pariwisata yang dipekerjakan di Tanjung Lesung akan segera memenuhi sertifikasi minimum standar MRA-TP, sesuai dengan perjanjian negara-negara ASEAN pada 9 November 2012 di Bangkok, yang direvisi pada 6 Agustus 2016, khususnya di bidang jasa hotel dan layanan perjalanan. Sektor jasa hotel meliputi 4 divisi dan 23 subdivisi, yaitu: (1) Front office(manajer kantor, pengawas kantor depan, resepsionis, operator telepon, bell boy), (2) Housekeeping (pembantu rumah tangga eksekutif, manajer binatu, pengawas lantai, petugas binatu, petugas kamar, pembersih area publik, (3) Food production (executive chef, demi chef, commis chef, chef de partie, commis pastry, baker, butcher), (4) Food and beverage service $(F \& B$ director, $F \& B$ outlet manager, head waiter, bartender, waiter).

Bidang jasa perjalanan meliputi 2 divisi dan 9 sub divisi, yaitu: (1) Travel agencies (general manager, assistant general manager, senior travel consultants, travel consultants), (2) tour operations (product manager, sales dan marketing manager, credit manager, ticketing manager, tour manager).

\section{Langkah Percepatan}

Percepatan

destinasi prioritas Tanjung Lesung, membutuhkan investasi yang berkomitmen pentahelix yakni melalui peningkatan jumlah dan kualitas sumber daya manusia, serta diperlukan promosi berkelanjutan. Selain itu, diperlukan pula kerja sama dengan semua pihak termasuk 
International Travel Agencies (TAs) atau Tour Operator (TOs). Harapannya, hal itu akan mendorong peningkatan kunjungan wisatawan ke Tanjung Lesung. Dengan datangnya lebih banyak wisatawan, semakin banyak lapangan kerja yang akan dibuka, pendapatan masyarakat akan meningkat, pertumbuhan ekonomi akan positif, dan lingkungan akan lebih baik dikonyani. Belanja wisatawan mancanegara pada 2018 adalah USD 1.200 dan Rp. 1.200.000.000 untuk wisatawan domestik.

\section{New model}

Model baru perlu dipekerjakan dalam promosi destinasi Tanjung Lesung, yaitu melalui implementasi pendekatan Community-Based Tourism Management (CBTM), bukan pendekatan yang dipimpin pemerintah dan industri (GSIL) saat ini. GSIL hanya akan menciptakan kesenjangan antara pengembangan industri di destinasi pariwisata dan masyarakat sekitar, atau bahkan menciptakan ketergantungan masyarakat terhadap industri di destinasi tersebut. Dalam jangka panjang, akan menciptakan konflik sosial, ekonomi, dan lingkungan karena masyarakat dijadikan objek ketimbang tunduk pada pengembangan pariwisata. Sementara itu, CBTM diyakini dapat mengembangkan pariwisata yang komprehensif, yang berorientasi pada kemajuan dan kemakmuran bersama, misalnya, pariwisata berbasis budaya akan mudah berkembang, barang pelengkap pariwisata akan lebih bervariasi, dan pariwisata akan menjadi kekuatan baru dan bersama di lingkungan yang bersangkutan. Langkah yang akan diambil antara lain membangun kerja tim mulai dari perencanaan, penyelenggaraan, pelaksanaan, dan pengendalian (Planning, Organizing, Actuating, and Controlling atau POAC) dalam setiap upaya pengembangan destinasi pariwisata.

\section{KESIMPULAN}

$\begin{array}{crrr}\text { Destinasi Tanjung } & \text { Lesung } \\ \text { memiliki potensi } & \text { besar } & \text { untuk }\end{array}$ dikembangkan sebagai destinasi wisata kelas internasional, dipertimbangkan dari alam, budaya, serta atraksi buatan manusia. Namun, investasi besar diperlukan untuk mempercepat kemajuannya, terutama yang terkait dengan pengembangan 3-A (aksesibilitas, atraksi, dan fasilitas). Selanjutnya, diperlukan partisipasi yang lebih proaktif dari pentahelix ABGCM (akademisi, bisnis, pemerintah, masyarakat dan media). Promosi destinasi pariwisata perlu dilakukan melalui berbagai saluran POSE (media berbayar, media sendiri, dan media sosial), didukung dengan penyediaan SDM pariwisata yang berkualitas, berdaya saing, dan memiliki kompetensi berstandar internasional.

Destinasi ini perlu mengimplementasikan model CBTM (community based tourism management) agar tujuan pengembangan pariwisata yang pro-job oriented, pro-poor, progrowth, dan pro-environment secara berkelanjutan dapat terwujud, dan tidak menciptakan konflik sosial, ekonomi, dan lingkungan di masa depan. Kolaborasi dengan berbagai pihak perlu dikembangkan dan ditindaklanjuti secara berkelanjutan, khususnya dalam setiap aspek manajemen (POAC).

\section{DAFTAR PUSTAKA}

BPS, D. J. (2019). Provinsi DKI Dalam Angka 2019 (DKI Jakarta inFigures). Jakarta: BPS DKI Jakarta Publisher.

Bramwell, B., Higham, J., Lane, B., \& Miller, G. (2017). Twenty-five years of sustainable tourism and the Journal of Sustainable Tourism: looking back and moving forward. Journal of Sustainable Tourism, 25(1), $1-9$. 
https://doi.org/10.1080/09669582.20 17.1251689

Buckley, R. (2012). Sustainable tourism: Research and reality. In Annals of Tourism Research. https://doi.org/10.1016/j.annals.2012 .02 .003

Dibra, M. (2015). Rogers Theory on Diffusion of Innovation-The Most Appropriate Theoretical Model in the Study of Factors Influencing the Integration of Sustainability in Tourism Businesses. Procedia Social and Behavioral Sciences. https://doi.org/10.1016/j.sbspro.2015 .06 .443

Franjaya, E. E., \& Prastiwi, I. (2020). Study on Tourism Potency and Planning of Techno-Edu Tourism in Institut Teknologi Sumatera. IOP Conference Series: Earth and Environmental Science, 501, 012021. https://doi.org/10.1088/1755-

1315/501/1/012021

Kemenpar. (2016). Pembangunan Destinasi Pariwisata Prioritas 2016 2019. Rapat Koordinasi Nasional Kementerian Pariwisata "Akselerasi Pembangunan Kepariwisataan Dalam Rangka Pencapaian Target 12 Juta Wisman Dan 260 Juta Wisnus 2016."

Kiper, T. (2013). Role of Ecotourism in Sustainable Development. In Advances in Landscape Architecture. https://doi.org/10.5772/55749

Kurniawati, E., Hamid, D., \& Hakim, L. (2018). Peran Masyarakat dalam Perencanaan dan Pengembangan Desa Wisata Tulungejo Kecamatan Bumiaji Kota Batu. Jurnal Administrasi Bisnis (JAB), 54(1), 814. administrasibisnis.studentjournal.ub. ac.id\%0A8

Leslie, D. (2015). Responsible Tourism . Glasgow UK : Caledonian University.
Lohmann, G. (2018). Tourism Theory . Brisbane : Griffith University .

Lu, J., \& Nepal, S. K. (2009). Sustainable tourism research: An analysis of papers published in the Journal of Sustainable Tourism. Journal of Sustainable Tourism, 17(1), 5-16. https://doi.org/10.1080/09669580802 582480

Ministry of Tourism RI. (2018). LITBANGJAKPAR (Tourism Policy R \& D) Research Journal. Research Journal of Ministry of Tourism.

Morpeth, M. (2015). Planning for Tourism. UK Leeds: Leeds Beckett University.

World Travel \& Tourism Council. (2018). Travel \& Tourism Economic Impact 2018 World. Travel and Tourism Impact 2018. https://doi.org/10.1093/elt/ccr029 